\title{
$10 \mathrm{GHz}$ 帯高仰角伝搬時の降雨減衰特性
}

\author{
NHK 総合技術研究所金原晃
}

放送衛星など $10 \mathrm{GHz}$ 以上のマイクロ波を使用した衛星・地上間通信の回線設計で最も重要なパ ラメーターである高仰角の降雨減衰量につき, 観測方法とその結果を述べた. 減衰量の観測は, 太 陽雑音，大気雑音を受信し，その雑音温度から換算する方法によった．当所での観測は $11.8 \mathrm{GHz}$ を受信し, 同時に降雨強度の測定をそれぞれ連続で行なっている. また, 上空の雨雲の構造を気象 レーダーによる観測例により調査した. 上記の観測から, 地上の瞬時降雨強度と減衰量の関係を求 ぬ，降雨資料から実験的に減衰量を推定する方法を提案した。

\section{1. まえがき}

現在, 衛星・地上間の実用回線には $7 \mathrm{GHz}$ 以下のマイ クロ波が利用されているが, 将来予想される通信量の増 加に対処するために $10 \mathrm{GHz}$ 以上の電波す使用すると之 が考えられ，また，放送衛星用としても $12 \mathrm{GHz}$ 带が候 補に上っている.

しかし，10GHz 以上のマイクロ波回線では，大気圈 の雨, 雪, 霰, 承晶などによる減衰が大きく, また酸素 や水蒸気の分子により特定の周波数帯域で大きな隇衰を 生じるととが知られている11.

上記の帯域で最も大きな減衰を生じるのは降雨で，そ の影響はとくに地上の低仰角回線で著しい，そのために 古くから降雨減衰の理論的ならびに実験的研究が行なわ れて, その結果として地上回線については $35 \mathrm{GHz}$ 帯ま での回線設計に役立つ基碟資料が得られている ${ }^{1)-3)}$.

しかし, 衛星通信のような高仰角の伝搬に求ける降雨 減衰は新しい研究課題で, 数多くの未解決の間題を残し ている，その主な理由は，乙の種の研究に対する要求が 高まったのが比較的近年であるとと，上空の雨域構造や 降雨の測定ならびに伝搬実験が地上波の場合よりも困難 なためである.

当研究所では, 衛星を放送に利用する研究の一環とし て 1967 年加ら高仰角伝搬の研究に着手し，太陽雑音抒 よび大気雑音を利用した降雨隇衰量の観測を行なってい る. 本文では，乙れらの観測法とその結果を中心に報告

\footnotetext{
"Attenuation due to Precipitation in the $10 \mathrm{GHz}$ Band at the Propagation with Higher Angles of Elevation" by Akira Kinpara (NHK Technical Research Laboratories, Tokyo)
}

し，さらにレーダーを使用して上空の雨域構造を観測す る方法にもふれている。なお，最近種々の機関でもての 方面の研究を開始している. すなわち, 電気通信研究所 では1969 年から観测を開始し, 電波研究所, KDD 研究 所で屯計画を進めている. 諸外国では, Bell 研究所)で 1967年から観測を行なっているほか，英国が観測法の標 準化を CCIR に提案している5 .

\section{2. 減衰量の観測方法}

\section{1 観測方法のあらまし}

高仰角電波伝搬の観測は, 静止衛星の電波を連続受信 して，低仰角の場合と同様な観測および解析を行なうこ とが望ましいが, 現状では信号源が得難いので, 当所で は容易に実施できる次の観測方法を採用している.

（i）大気雑音を観測して, 減衰量を推定する.

（ii）太陽雑音を受信し，その減衰加ら降雨減衰量を 推定する.

（iii）気象研究所のレーダーで観測した雨雲のデータ から上空の雨滴分布を求めて, てれから減衰量を推 定する.

これらの方法のうち，（ｉ）と（ii)を比較すると，滅衰 量が大きいときは(ii)の方法が，減衰量が小さいときは (i)の方法が他方よりあ精度が良い. 本研究の目的は減 衰量が大きいときを対象としているので，（ii）の方法を 優先し，昼間は（ii）の方法を，夜間は（i）の方法を採用 し $11.8 \mathrm{GHz}$ で連続観測をしている. このほか, 1956 年 から名大空電研究所で続けられている $9.4 \mathrm{GHz}$ での太 陽雑音の観測資料からも (ii)の方法で減衰量を推定して いる. 
（iii）の方法は, レーダーで各高度からの雨雲による反 射波の強度を観測するもので, 減衰量の測定よりも上空 の雨域構造の解析に利用する目的で観測資料の解析を進 めている.

\section{2 大気雑音を観測する方法}

受信空中線を天空に向けたときに受信される雑音のう ち, 大気圈加ら発生する雑音 (以後, 大気雑音之呼ぶ) から減衰量を推定する方法である.

この大気雑音は微弱であるが, 発生機構からみて受信 機内部雑音などと比較しておそい周期の変動のみに注目 すればよいので，次に述べるディッケ形受信機を用いて 観測する.との受信機は, 受信信号 (大気雑音) と常温 負荷から発生する標準雑音とを比較して測定する．すな わち，雨者をスイッチで切替えて受信し，てれを同期検 波器で復調する之受信雑音電力に比例した出力が得られ る. この受信機は検波回路の時定数を大きくとっている ので, 標準雑音と受信雑音の平均された值の差が出力に 現われる. この受信機の感度は検波出力のふらつきによ りきまるが，乙のふらつきは雑音の統計的性質により (雑音指数) /(受信带域幅 $\times$ 検波時定数 $)^{1 / 2}$ 亿比例する. そこで受信帯域幅と検波時定数を大きく選べば，受信機 内部雑音よりむはるかに小さい雑音を測定できる6).

当所の受信機の接続を図 1 亿, その特性を表 1 亿示す. との受信機では, 利得のゆるやかな変動により生じる誤 差を防止するために，標準雑音源で 1 時間に 1 回利得の 自動較正をする，標準雑音源には雑音放電管を使用し， 点火時の雑音温度を尺度にして雑音を測定する. 図 1 の
表 1 ディッケ方式受信装置特性

\begin{tabular}{lr|c}
\hline 受信中心周波数 & $(\mathrm{MHz})$ & 11,830 および 11, 770 \\
受信周波数帯域幅 & $(\mathrm{MHz})$ & 10 \\
局部発振器周波数 & $(\mathrm{MHz})$ & 11,800 \\
雑音指数 & $(\mathrm{dB})$ & 10 \\
$\quad$ (SSB) & & \\
ディッケ変調周波数 & $(\mathrm{Hz})$ & 223 \\
検波後の積分時定数 & $(\mathrm{sec})$ & 1 \\
空中線直径 & $(\mathrm{m})$ & $1 \phi$ \\
空中線利得 & $(\mathrm{dB})$ & 38 \\
$\quad$ 空中線開口角 & $\left({ }^{\circ}\right)$ & 180 \\
\hline
\end{tabular}

受信機で雑音放電管を点火したときに入力に加えられる 雑音温度 $T_{n}$ は,

$$
\begin{aligned}
T_{n} & =(\text { 放電管雑音 }) \times(\text { 方向性結合器結合度 }) \\
& =11,100 \times(1 / 69)=160.5\left({ }^{\circ} \mathrm{K}\right)
\end{aligned}
$$

大気雑音および標準雑音検波出力をそれぞれ $m_{a}, m_{n}$ とすると, 大気雑音温度 $T_{a}$ は (付録 1 (付·6) 式参照),

$$
T_{a}=T_{0 s}-m_{a} T_{n} /\left(m_{n}-m_{a}\right)
$$

ただし，常温負荷の温度： $T_{0 s}=333^{\circ} \mathrm{K}$ 放電管の雑音温度 : $11,100^{\circ} \mathrm{K}$ 方向性結合器結合度： $-18.4 \mathrm{~dB}(1 / 69)$

一方, 降雨による減衰量 $A$ は, 周知のように自由空間 伝搬を規準にして距離 $r$ の点の減衰定数 $\alpha$ が減衰層 $r_{1}$ から $r_{2}$ まで分布している場合に，(3) 式で与えられる.

$$
A=\exp \left(-\int_{r_{1}}^{r_{2}} \alpha d r\right)
$$

乙の減衰定数 $\alpha$ は雨滴の電波に対する等価減衰断面皘 (cross section) $Q_{T}(D)$ の和として，(4)式で与えられ る $^{1)-3)}$ (付録 2 参照).

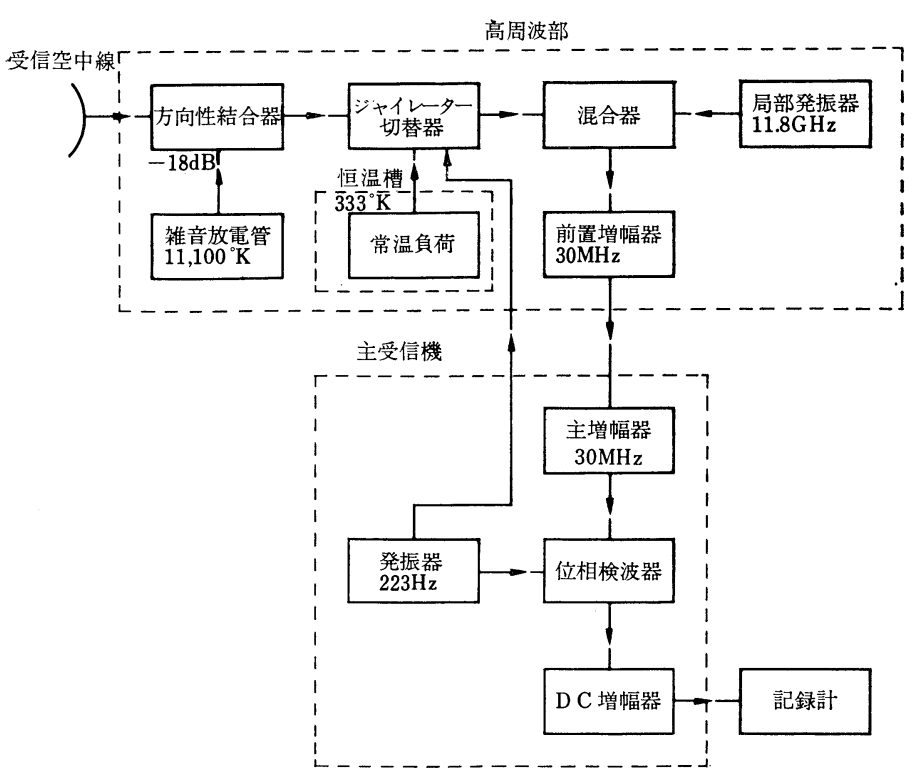

図 1 ディッケ形受信機

Block diagram of radiomenter. (Dicke type)

$$
\alpha=\int_{0}^{\infty} N_{D} Q_{T}(D) d D
$$

$D$ : 雨滴の直径, $N_{D}$ : 単位体積 中に分布する直径 $D$ の雨滴の 粒子数

水滴を誘電体球として境界值から解析 した結果によると，波長 $\lambda$ が $\lambda \gg D$ の とき $Q_{T}(D) \propto D^{3}$ となる. (4) 式の $N_{D}$ は当然降雨強度の関数となる. との関係 は Laws \& Parsons ${ }^{7)} や$ Ryde $ら^{3)}$ により 観測され，その結果を用いて一様な降雨 に対する降雨強度と減衰率の関係が(5) 式で与えられている.

$$
10 \log A=K R^{r}(\mathrm{~dB} / \mathrm{km})
$$

$R:$ 降雨強度 $(\mathrm{mm} / \mathrm{h}), K$ と $\gamma$ は周波 数できまる定数で， $R$ と $A$ は図 2 の関 係となる ${ }^{8)}$. 図 2 によると $11.8 \mathrm{GHz}$ では 同じ $R$ に対して $9.4 \mathrm{GHz}$ の $\mathrm{dB}$ で約 2 倍の減衰を生じることがわかる。 


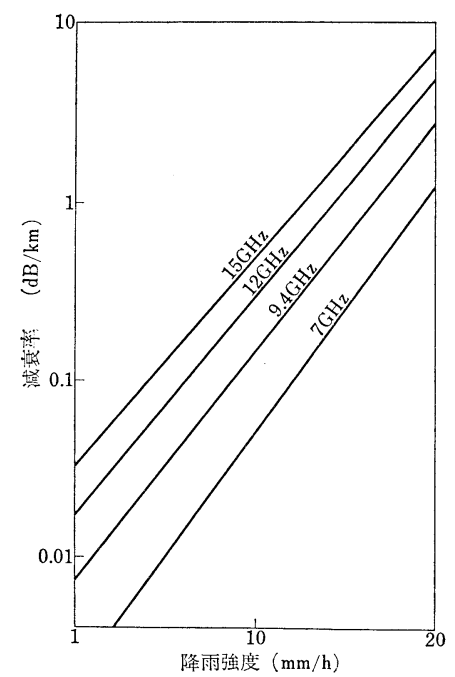

図 2 降雨強度と減衰率の関係（計算值）

Relation between the attenuation rate and the rain fall rate derived from theoretical value.

このように減衰により生じる雑音温度 $T_{a}$ の計算には 従来は, 抵抗減衰器加ら発生する熱雑音と同様と考えた (6)式が使用されてきだ).

$$
T_{a}=\int_{0}^{\infty} T \alpha \exp \left(-\int_{0}^{n} \alpha d r\right) d r
$$

$T$ : 減衰層の温度 $\left({ }^{\circ} \mathrm{K}\right), r$ : 減衰層の貫通距離 しかし，乙の式は理論的に正確ではない.すなわち， 電波の減衰を生じる水滴の誘電率を $\varepsilon_{1}-j \varepsilon_{2}$ とすると ${ }^{10)}$ この誘電体球による減衰は $\varepsilon_{2}$ により生じる吸収の他に と 1 による散乱がある．そこで，筆者はこの散乱を考慮し て(6)式に次のような補正を加えた.

まず, $Q_{T}(D)$ を解析結果の吸収断面積 $Q_{A}(D)$ と散 乱断面積 $Q_{S}(D)$ とに分離して，それぞれの減衰定数を $\alpha_{A}, \alpha_{S}$ とする. このうち $\alpha_{A}$ により生じる雑音温度は, (6)式と同様であるが，散乱による減衰定数 $\alpha_{S}$ につい てみると，乙の種の減衰により発生する雑音はないが, 地面から放射される熱雑音が雨滴で散乱されて受信され る雑音を考えなくてはならない，したがって，てれを考 慮すると大気雑音は (7) 式のようになる (付録 2 参照).

$$
\begin{gathered}
T_{a}=\int_{0}^{\infty} T_{A} \alpha_{A} \exp \left(-\int_{0}^{r} \alpha d r\right) d r \\
+\int_{0}^{\infty} T_{B} \alpha_{B} \exp \left(-\int_{0}^{r} \alpha d r\right) d r
\end{gathered}
$$

ここで,

$$
\alpha=\alpha_{A}+\alpha_{B}+\alpha_{F}
$$

ただし， $T_{A}, T_{B}$ はそれぞれ雑音発生源の温度， $\alpha_{A}, \alpha_{B}$, $\alpha_{F}$ おのおの吸収, 後方散乱, 前方散乱による減衰定数. これらのうち $\alpha_{F}$ は受信雑音温度に関係しない.

この $\alpha_{A}, \alpha_{B}, \alpha_{F}$ はそれぞれの等価断面積 $Q_{A}(D), Q_{B}$

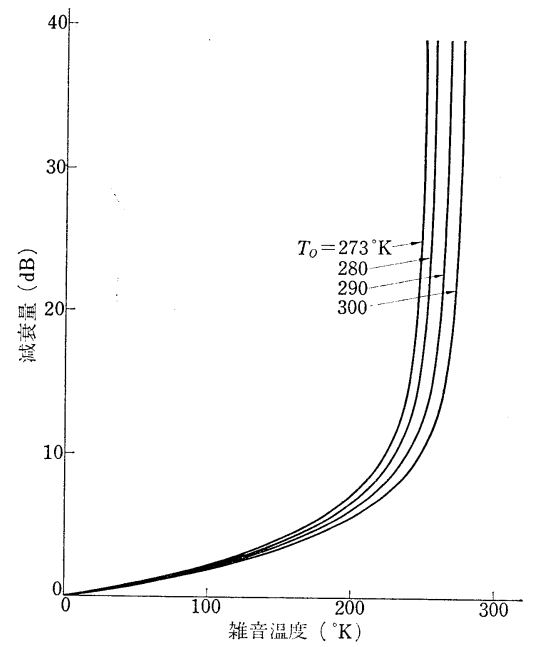

図 3 雑音温度と減衰量の関係

Loss as a function of $T_{a}$ through a layer of uniform precipitation.

$(D), Q_{F}(D)$ と上記の Ryde の観測例による $N_{D}$ とか ら (4) 式と同様の方法で求めた. これらの $\alpha_{A}, \alpha_{B}, \alpha_{F}$ を (7) 式に与えて計算した減衰量と雑音温度を図了に示 す.この計算は雨域内の降雨が一定でその厚さが $3 \mathrm{~km}$, 温度 $T_{A}$ は高度が高くなるのにしたがって $7^{0} / \mathrm{km}$ で低下 し， $T_{B}$ は地面が雑音源なので地上の温度 $T_{0}$ という雨 域のモデルを仮定して行なった.

次に，乙の換算法の精度を検討する．との計算では， $r_{t}=3 \mathrm{~km}$ としたが，実際の雨では変化することが予想 されるので, 極端な例として（3) 式による減衰量が一定 であ雨が $10 \mathrm{~km}$ まで一様に分布しているときと，0のと ころに集中しているときの雑音温度とを $r_{t}=3 \mathrm{~km}$ のと きと比較しても，その差 $\Delta T_{a}$ は図 4 に示すように雑音 温度で $6^{\circ}$ 以下，比率でも $10 \%$ 以下で，しかも減衰量 が小さいときに比率は大きいので，乙のために生じる誤 差は図 3 の勾配からみて小さい. な拉，

$$
\left.\Delta T_{a}=\mid T_{a}-T_{a(r t=3 \mathrm{~km})}-T_{a(r t=0} \text { or } 10 \mathrm{~km}\right) \mid
$$

しかし，図３の曲線は雑音温度が高くなると，その勾 配が大きくなるので，とのような場合は $T_{a}$ の誤差が換

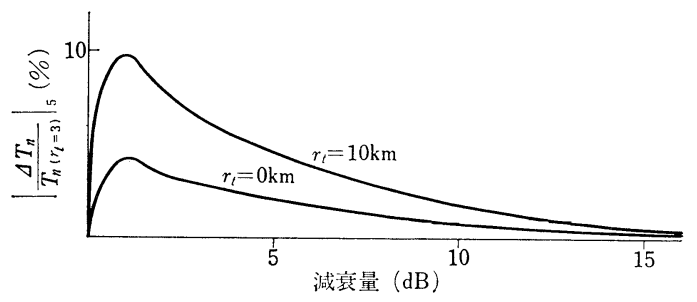

図 4 減衰層の厚さが変化したときに生じる誤差標準 $(r t=3 \mathrm{~km})$

Error caused by the thickness of the precipitation layer. 
算した減衰量では大きな差になる，したがって，ての観 測法は大きな減衰量の測定にはあまり適さない。

この方法で大気雑音から換算した隇衰量を電気通信研 究所の観測結果を用いて検定する。通研では太陽雑音と 大気雑音を独立に同時に観測し， 2.3 節の (10) 式で減 衰量を求めている。通研の報告 ${ }^{11)}$ 亿は，乙の減衰と(6) 式を集中定数にした $T_{a}=T(1-A)$ により求めた減衰量 あまた発表している，そてで上式で求めた結果をての式 と (7) 式の差で補正すると，ほぼ前者の結果と一致する ので，とのととから(7)式の方法は実験的にも裏付けさ れた。

\section{3 太陽雑音による方法}

この方法は太陽を信号源として利用する方法である. 太陽から放射される雑音電波には太陽面の黒体放射によ る雑音と爆発により発生する雑音とがあるが，ここでは ほぼ一定の電力を連続放射する前者注目する.

この雑音の変動は, 降雨などによる減衰量の変化より 屯周期が長く, 振幅が小さいので, 太陽雑音を高仰角伝 搬観測の信号源として利用できる。

太陽雑音は上記のディッケ形受信機で受信し，空中線 は赤道儀で自動的に太陽を追尾する.太陽自体の $12 \mathrm{GHz}$ 帯での雑音温度は $10,000^{\circ} \mathrm{K}$ 以上あるが，受信空中線の 視半径は表 1 のよう $1.5^{\circ}$ で太陽の視半径約 $16^{\prime}$ より あ広いので, 実効的な受信雑音温度 $T_{s}$ は約 $520^{\circ} \mathrm{K}$ (晴 天時の観測值）となる.

受信雑音温度 $T_{r}$ 之減衰量 $A_{\theta}$ との関係は, 上記の $T_{s}$ と $T_{a}$ を用いて(10)式となる.

$$
T_{r}=T_{s} A_{\theta}+T_{a}
$$

(10)式の雑音温度のうち $T_{s}$ は上記の観測值が利用で きる．また， $T_{r}$ は観測值であるが， $T_{a}$ は同時に観測で

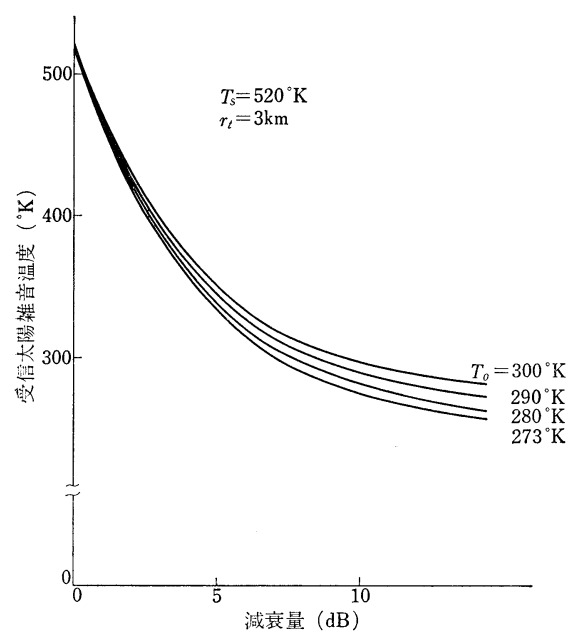

図 5 減衰量と受信太陽雑音温度の関係

Loss as a function of receiving Solar radiation.
きないので（7)式により $A_{\theta}$ から近似的に求めた值を 用いて (10)式から $A_{\theta}$ と $T_{r}$ の関係を求める. 乙の計算 結果は図 5 となるので，乙の関係を用いて $T_{r}$ 加 $A_{\theta}$ を換算している ${ }^{12)}$.

太陽の仰角は時刻とと屯に変化するので, 観測した減 衰量は cosec 則, すなわち減衰層の貫通距離が仰角の cosec に比例するとし，静止衛星*を考慮して仰角 $45^{\circ}$ に 換算した.

$$
\begin{aligned}
& 10 \log A_{n}=10 \log A_{\theta} \frac{\sin \theta}{\sin 45^{\circ}} \text { (dB) } \\
& \text { ただし, } \theta=\text { =観測時の太陽の仰角, } A_{n}=\text { 規準化 } \\
& \text { 減衰量 }
\end{aligned}
$$

\section{4 レーダー観測による方法}

との方法は, レーダーで雨雲の各高度からの反射電波 強度 $z$ を観測する． $z$ は受信電界強度を反射点までの距 離損失とレーダー定数で補正した雨の等価断面積を示す 因子で, 乙の $z$ と降雨強度 $R$ との関係は雨滴の直径分 布 $N_{D}$ とその直径と落下速度との関係から導びかれた (12)式が知られている ${ }^{13)}$. ただし， $B, \beta$ は上記の降雨 特性加ら求まる定数.

$$
z=B R^{\beta}
$$

$z$ の観測值の高度および時間変化加ら雨域構造や bright band（気温 $0^{\circ} \mathrm{C}$ 層，みぞれの状態で反射と減衰が大 きい）などの気象状態がわかる.

さらに，(12) 式で求めた $R$ を(5)式に用いると減衰 率 $A_{r}$ は,

$$
10 \log A_{r}=K\left(\frac{z}{B}\right)^{\gamma / \beta}(\mathrm{dB} / \mathrm{km})
$$

となる ${ }^{14)}$. (13) 式を用いればレーダー観測資料の $z$ から 総減衰量を積算できるが, (12), (13) 式の定数 $B, \beta$ は雨 の種類や地域により変化するてとが知られていて，今後 さらに調查を進める必要がある.

\section{3. 降雨減衰の観測結果}

東京で $11.8 \mathrm{GHz}$ で 1967 年 9 月 1969 年 12 月に観測 した，太陽雑音と夜間の大気雑音，豊川の $9.4 \mathrm{GHz}$ の 1964 年 8 月〜 1969 年 8 月の太陽雑音をそれぞれ集計し た統計量と, これらから得た降雨と減衰量との関係, さ らに降雨の資料から実験的に減衰量を推定する方法につ いて明らかになった点を述べる. また，レーダーによる 観測例加求めた上空の雨域構造と減衰量についてもふ れる。

\section{1 減衰量**之降雨強度の統計量の関係 ${ }^{15)}$}

* 日本向けの静止衛星を東径 $135^{2}$ の赤道上に打上げると，仰角は東 京で $48^{\circ}$, 札幌で $40^{\circ}$, 九州南端で $54^{\circ}$ となるので, 代表的な仰角と して $45^{\circ}$ を採った.

** 以後減衰量とは規準化した減衰量を指す. 


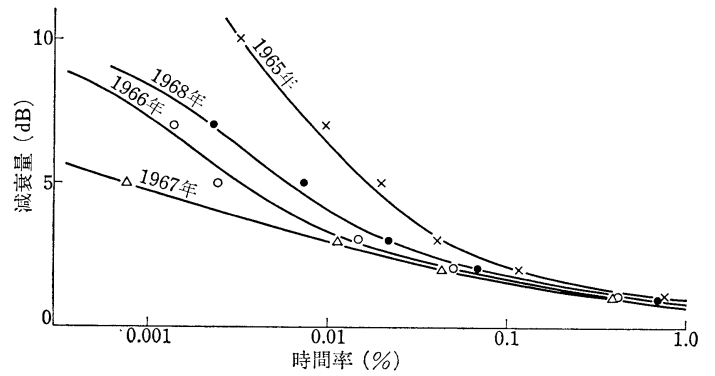

図 6 減衰量が縦軸の值を越す時間率（豊川 $9.4 \mathrm{GHz}$ )

Percentage of time to attenuation due to pricipitation duration.

表 2 年間総降水量

\begin{tabular}{|c|c|c|c|}
\hline 年 & 度 & 年間総降水量 $(\mathrm{mm})$ & 平均との比較 \\
\hline \multicolumn{2}{|c|}{1959} & 1601.0 & 102.3 \\
\hline \multicolumn{2}{|c|}{1961} & 12602 & 81.0 \\
\hline \multicolumn{2}{|c|}{1962} & 1256.0 & 80.0 \\
\hline \multicolumn{2}{|c|}{1963} & 1575.5 & 101.0 \\
\hline \multicolumn{2}{|c|}{1964} & 1138.9 & 73.0 \\
\hline \multicolumn{2}{|c|}{1965} & 1596.0 & 102.0 \\
\hline \multicolumn{2}{|c|}{1966} & 1643.5 & 105.0 \\
\hline \multicolumn{2}{|c|}{1967} & 1023.3 & 65.5 \\
\hline \multicolumn{2}{|c|}{1968} & 1491.0 & 95.5 \\
\hline \multicolumn{2}{|c|}{ 平均* } & 1563.0 & 100.0 \\
\hline \multicolumn{4}{|c|}{$\begin{array}{l}\text { * 平均值は } 1931 \text { 1960 の } 30 \text { 年間の平均（理科年表による） } \\
\text { 年間総降水量はお天気相談所提供の資料による }\end{array}$} \\
\hline \multicolumn{4}{|c|}{ 豊 川 } \\
\hline \multicolumn{2}{|c|}{ 年＼cjkstart度 } & 年間総降水量 (mm) & 平均との比較 \\
\hline \multicolumn{2}{|c|}{1965} & 1598 & 139 \\
\hline \multicolumn{2}{|c|}{1966} & 1237 & 100 \\
\hline \multicolumn{2}{|c|}{1967} & 753 & 61 \\
\hline \multicolumn{2}{|c|}{1968} & 1352 & 109 \\
\hline & 均 & 1235 & 100 \\
\hline
\end{tabular}

建設省の資料による. 観測期間は 4 月 1 日〜 12月 15 日

$9.4 \mathrm{GHz}$ の観測資料を集計した年単位減衰量の時間率 は図 6 のように時間率 $0.03 \%$ 以下では同一時間率に対 する減衰量が年度により大きく変動する，一方，同一期 間の年間降水量は表 2 のように同じ傾向で変化するが東 京, 豊川ともにそのばらつきは小さい。このととは平年 よりあ多雨の年は大きな減衰を生じる強雨発生回数の比 率が大きいととを示す．とのととから大きな減衰量の時 間分布を知るためには，総雨量ではなく瞬時の降雨強度 を知る必要があるととがわかる.

次に，減衰量と 1967 年末からそれぞれの受信点で観 測している降雨強度との抢の扔のの年単位の時間分布 は，図 7 のように互いに相似の傾向を持っているので, この関係を用いて降雨強度時間分布から減衰量時間分布 を推定する一方法として等価貫通距離を考えた。

ての方法は, 雨が一定の高度まで地上と同じ状態で一 様に降っていて, その雨域の中では既知の降雨強度と減

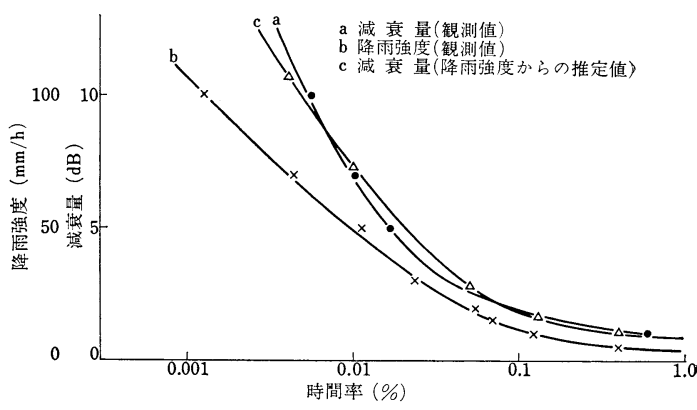

(a) 東京 $11.8 \mathrm{GHz}$

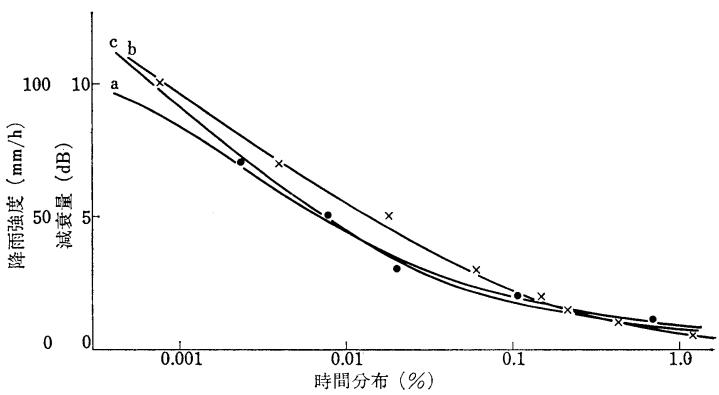

(b) 豊川 $9.4 \mathrm{GHz}$

図 7 減衰量および降雨強度の值が縦軸の值を越す時間率 Percentage of time to attenuation and rate of surface rain fall.

衰量の関係が適用できると仮定する。この式を用いて降 雨強度之同じ時間率における減衰量値加ら換算した雨域 の厚さ，すなわち，等価貫通距離は $30 \mathrm{~mm} / \mathrm{h}$ 以上の雨 では $11.8 \mathrm{GHz} ， 9.4 \mathrm{GHz}$ とも約 $3.3 \mathrm{~km}$ となる．た だし，雨が弱いときは雨雲による減衰が無視できないの で，その值は厚くなる．雨雲による減衰は約 $1 \mathrm{~dB}$ が観 測されているので，乙れを観測した減衰量から差引くと 等価貫通距離は降雨強度に関係なく約 $3.3 \mathrm{~km}$ となる. そこで，以上の関係を用いて降雨強度時間分布から減衰 量の時間分布を推定すると図 7 の曲線 $\mathrm{c}$ となり，広範囲 にわたり実測値と一致する.

今回集計した期間に観測された最大の減衰量としては

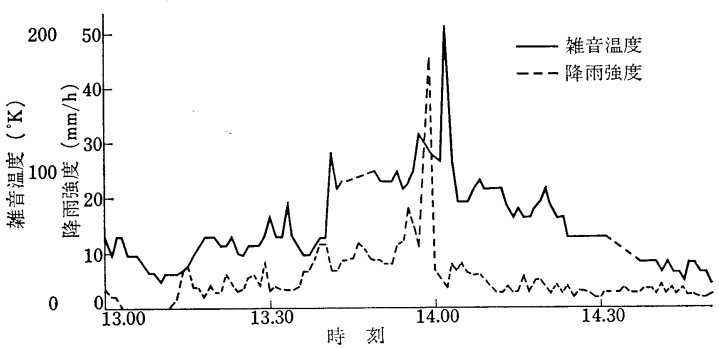

図 8（a） 雑音温度と降雨強度の同時観測記録（東京 11.8 $\mathrm{GHz}, 1967.11 .30$ )

Example of correlation between measured surface rain fall rate and sky-noise temperature. 


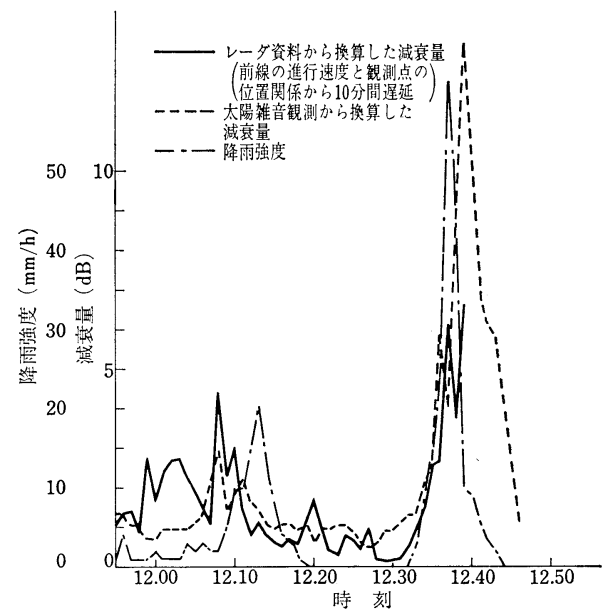

図 8(b) 降雨強度と減衰量の同時観測記録（東京 118 $\mathrm{GHz}, 1969.5 .17$ )

Example of correlation between measured surface rain fall rate and attenuation due to precipitation.

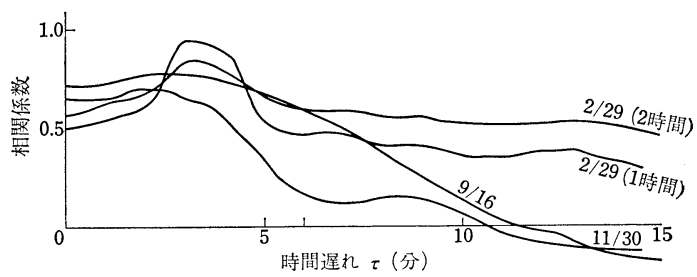

図 9 降雨強度之雑音温度の相関 (東京 $11.8 \mathrm{GHz}$ )

Crosscorrelation function between surface rain fall rate and sky-noise temperature.

東京で 1968 年 9 月 5 日の霖を伴った雷雨により約 $15 \mathrm{~dB}$ が観測された。 この雷雨の最大の降雨強度 (1 分間) は $263 \mathrm{~mm} / \mathrm{h}$ であった. ただし, 日没前後の仰角の低いと きは貫通距離が長いため観測不能（減衰量無限大）の場 合ああった。

豊川では, 1965 年 9 月に $12 \mathrm{~dB}$ が観測された。

\section{2 減衰量と降雨強度の同時観測結果の相関}

図 8 亿減衰量之降雨強度の同時観測結果を示す. 両者

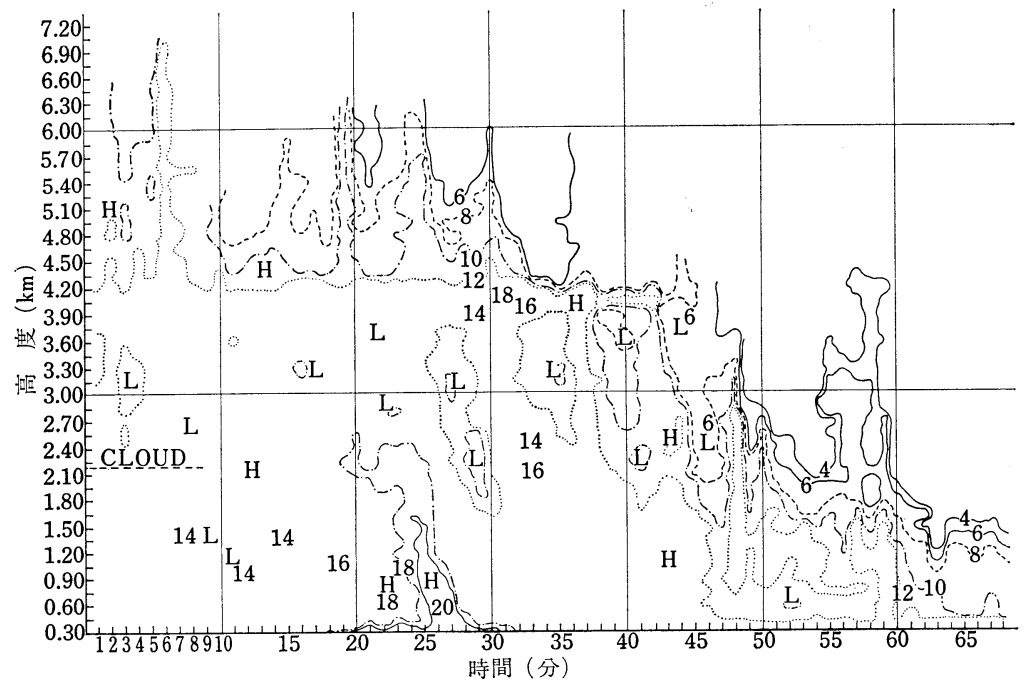

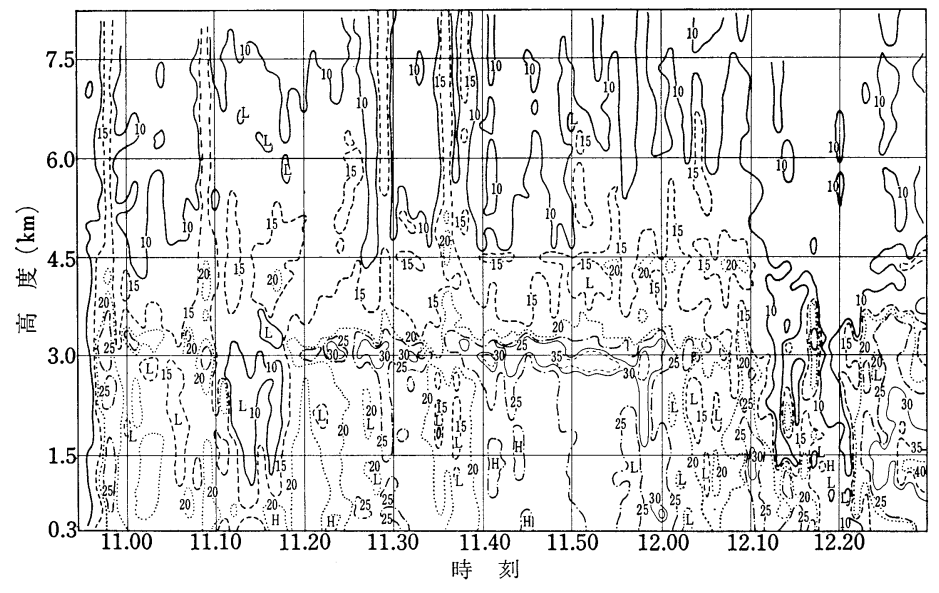

図 10 レーダで観測した雨域構造 Contour of " $Z$ " in the rain coloud, measured by meterological radar. 
表 3

\begin{tabular}{c|c|c|r|c}
\hline \hline 月 & 雨の状態 & $\begin{array}{c}\text { 降雨強度(最大) } \\
(\mathrm{mm} / \mathrm{h})\end{array}$ & \multicolumn{1}{c|}{$B$} & 時間的対応 \\
\hline '68. 8.26 & 低気压, 対流性 & 23 & 100 & やや不良 \\
'68.10.4 & 秋雨前線, 地雨性 & 10 & 50 & 良 \\
'69.5.17 & 寒冷前線, 対流性 & 62 & 150 & 良 \\
\hline
\end{tabular}

を照合すると，よく対応しているので相互相関を求める と図 9 となり, 降雨強度が減衰量より $2 \sim 3$ 分㯺れたと き最大の相関係数があらわれ $0.8 \sim 0.5$ となる. この值 は強い雨のとき大きい。

\section{3 レーダー観測結果から換算した減衰量}

レーダー観測の例として気象研究所（当所の $7.5 \mathrm{~km}$ 北 $15^{\circ}$ 東) のドプラーレーダー $(9.375 \mathrm{GHz}, 0.25 \mu \mathrm{s} /$ パ ルス,パルス繰返し周波数 $4 \mathrm{kHz}$ ) で観測した上空の雨 域分布を図 10 に示す. 1968 年 10 月 4 日の例では約 4 $\mathrm{km}$ に, 1969 年 5 月 17 日の場合は約 $3 \mathrm{~km}$ のところに 強い反射を示す bright band $\left(0^{\circ} \mathrm{C}\right.$ 層) がみられる.

次に, この $z$ の分布から(13)式で減衰率を求めて貫通

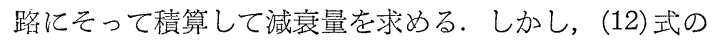
定数 $B$ は上述のように雨の種類により異なるので，(13) 式で求めた減衰量と当所で太陽雑音から求めた減衰量と の照合からBを求め，てれを表了に示した。 とのように 雷雨など対流性の雨では $B$ が大きく, 地雨性の場合は小 さい，乙のようにして求めた換算值と実測值の時間的対 応を見ると図 $8(\mathrm{~b})$ の例のように前線性の雨ではよく一 致した. 図 8 (b) では寒冷前線の通過速度を用いて测定 点間の時間ずれを補正した。しかし，低気圧性の雨の例 ではこのような良い対応は得られなかった。

以上の結果によると, 減衰は主として高度 $2 \sim 4 \mathrm{~km}$ に ある bright band 以下の $z$ が大きい範团で生じる. 一 方，zの分布を見ると，地面に近いほどその值が大きく なる傾向があるので，乙れを考えると上述の等価貫通距 離から推定した雨域の厚さ約 $2.3 \mathrm{~km}$ (仰角 $90^{\circ}$ ) は上記 の bright band の高さより少し低くなっていて, 統計量 として妥当な値と考えられる.

\section{5.むすび}

$11.8 \mathrm{GHz}$ と $9.4 \mathrm{GHz}$ の高仰角伝搬の観測から得られ た降雨減衰特性について，現在までに明らかになった経 果の要点は次のとおりである.

（1）太陽雑音および大気雑音を観測してそれぞれ降 雨減衰量を推定する方法は，両者とも減衰量が大きいと きに観測精度が低下するが，両者を比較すると，前者は 減衰量が大きいとき, 後者は小さいときに他方より精度 が良い。

（2）観測結果によると, 年単位の減衰量時間分布は, 図6, 図 7 により $11.8 \mathrm{GHz}$ で時間率 0.01\%(約 52 分)
に対減衰量は約 $7 \mathrm{~dB}$ (1968 年, 1969 年), $9.4 \mathrm{GHz}$ では 多雨の 1965 年で約 $7 \mathrm{~dB}$, 並通の年 (1968 年) で約 4.5 $\mathrm{dB}$ である.

（3）年単位の減衰量時間分布は図6のように時間率 0.03\% 以下の減衰量の值が年度により大きくばらつく.

（4）降雨減衰量を求めるためには，電波通路上の雨 域構造を知る必要がある. しかし, 観測結果によると降 雨強度と減衰量の統計量から, 雨域内の減衰率を一定と 仮定して等価的な減衰層（雨域）の貫通距離を求めると $11.8 \mathrm{GHz} ， 9.4 \mathrm{GHz}$ とあ約 $3.3 \mathrm{~km}$ となり，乙の関係を 用いて, 地上で観測した降雨強度から減衰量を推定でき る.

（5）地上で観測した降雨強度と減衰量との相関は, 減衰量とこれから $2 \sim 3$ 分痋れた降雨強度のものが最大 で，強雨では相関係数が大きく 0.8 となることあある.

（6）レーダー観湘資料の代表例について，その反射 強度から減衰量を換算し，乙れと太陽雑音から求めた結 果とを照合して時間的対応をみると, 前線性の雨では一 致する。

以上，東京と豊川で観測した降雨減衰の統計量を中心 に報告した．とのうち，（1）～(4)の結果は1969 年の CCIR に報告した ${ }^{16) 17)}$.

今後，さらに観測を続けて統計的解析を進めるととも に, レーダー観測等から得られる雨域構造の高度分有や 移動速度をあわせ用いて降雨減䘚の解析を進めたい.

この研究を進めるにあたり, 太陽雑音観測資料を提供 された名古屋大学空電研究所田中春夫教授, レーダー 観湘資料を提供された気象研究所内藤恵吉室長，ご指 導をいただいた遠藤敬二主任研究員, 安東平一郎部長, 木名瀬亮主任研究員に深く感謝する.

(昭和 43 年 6 月 4 日受付, 昭和 44 年 11 月 3 日再受付)

\section{〔参 考 文 献〕}

1) D. Kerr: Propagation of Short Radiowave, MIT Radiation Lab. Series 13, McGraw-Hill Book Co. (1951) 445, 664

2) J.A. Stratton: Electromagnetic Theory (1941) 563

3) J. W. Ryde and D. Ryde: Attenuation of Centimetre Waves by Rain, Hail and Clouds, Wartime SECRET REPORT sent to Ultra Short Wave Panel, Rep. No. 8516 (Aug. 1944) Rep. No. 8670 (May 1945), The Attenuation and Radar Echoes Produced at Centimetre Wave-Lengths by various Meteorological Phenomena, Physical and Royal Meteorological Societies Report (1947)

4) R.W. Wilson: Sun Tracker Measurements of Attenuation by Rain at 16 and $30 \mathrm{GHz}$, BSTJ, May-June (1969)

5) CCIR Doc. (U. K.) IV/245, Use of Frequency Bands Above $10 \mathrm{GHz}$ for Communication-Satellite Systems Measurement of Atmospheric Attenuation and Noise Using a Solar Radiometer, Submitted to the Final Meeting, CCIR, Geneva (1969)

6) R.H. Dicke: The Measurements of Thermal Radiation at Microwave Frequencies, The Rev. of Scientific Instruments, 17, 7 (1946)

7) J. O. Laws and D.A. Parsons: The Relation of Drop Size 
to Intensity, Trans. Am. Geophys. Union (1943) 452

8) CCIR Report, Influence of the Non-ionized Regions of the Atmosphere on the Propagation of Waves, Rep. 234-1, Oslo (1966)

CCIR Doc. V/10-E (Mar. 1965) (U. K.), V/101--E (Jan. 1966)

9) C. Hogg, et al.: The Effect of Rain and Water Vapor on Sky Noise at Centimetre Wavelengths, BSTJ, Sept. (1961)

10) J. A. Saxton: Dielectric Dispersion in Pure Polar Liquids at Very High Radio Frequencies, II, Relation of Experimental Results of Theory, Proc. Royal Soc. of London, 213: 1115

11）森田ほか：高仰角伝搬における $11 \mathrm{GHz}$ 带の降雨減衰测定結果， 信学会IA P 研究会資料 A P 70-3

12) 金原: $10 \mathrm{GHz}$ 帯の高仰角伝搬時の降雨減衰特性, 信学会 $\mathrm{AP}$ 研 究会資料 AP 68-23 (1968.6)

13）小平: 気象レーダの基礎, 気象研究ノート, No. 90 (1967)

14) 金原: $10 \mathrm{GHz}$ 帯高们角伝搬特性 (2), 信学会 AP 研究会資料 AP 69-21 (1967.7)

15) A. Kinase and A. Kinpara: Statistics of Attenuation due to Precipitation of Radio Waves in $10 \mathrm{GHz}$ Band at Higher Angle of Elevation, NHK Laboratories Note, No. 130, Aug. (1969)

16) CCIR Doc. (Japan) V/126, IV/316, Tropospheric Absorption and Refraction in Relation to Space Telecommunication Systems Statistics of Attenuation of Radio Waves Frequencies Above About $10 \mathrm{GHz}$ at Higher Angles of Elevation in Japan, submited to the Final Meeting, CCIR, Geneva (1969)

17) CCIR Doc. (Japan) V/1029, Method for Predicting the Long Term Statistics of Attenuation due to Precipitation of Radio Waves in the $10 \mathrm{GHz}$ Band at Higher Angles of Elevation in Japan.

18) CCIR SG 5, U. K. Contribution, No. 9, A Provisional Method for Estimating Radio and Total Slant Path Attenuation in the Atmosphere for Frequencies Between 4 and $40 \mathrm{GHz}$. Oct. (1970)

\section{〈付録 1〉 雑音温度の観測方法}

ディッケ形受信機で放電管の雑音を尺度として雑音温 度を観測する方法の烂細を次に述べる6).

雑音受信時, 雑音放電管点火時, ディッケ变調停止時 に受信される雑音温度をそれぞれ $T_{a m}, T_{n m}, T_{0 m}$ とする (ディッケ変調を停止すると常温負荷の雑音温度が受信 される)，雑音温度はすべて $\left({ }^{\circ} \mathrm{K}\right)$ とする.

$$
\begin{array}{ll}
T_{a m}=T_{a} \cdot L+T_{0} \cdot(1-L)+T_{f} & \text { (付 } \cdot 1) \\
T_{n m}=\left(T_{n}+T_{a}\right) L+T_{0}(1-L)+T_{f} & \text { (付 } \cdot 2) \\
T_{0 m}=T_{0}+T_{f} & \text { (付.3) }
\end{array}
$$

ただし， $T_{a}$ =入力回路損失を含めた大気雑音温度

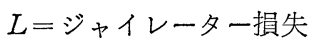

$$
\begin{aligned}
& T_{f}=\text { 受信機内部雑音温度 } \\
& T_{n}=\text { 雑音放電管 } \\
& T_{0}=\text { 常温（回路の温度） }
\end{aligned}
$$

ディッケ形受信機で雑音温度 $T$ の雑音を受信したと きの検波出力 $m$ は $m \propto\left|T_{0}-T\right|$ となるので, 乙の比 例定数を $K_{m}$ とすると $T_{a m}, T_{n m}$ に対する出力 $m_{a}, m_{n}$ は,

$$
\begin{array}{ll}
m_{n}=K_{m}\left|T_{0}-\left(T_{n}+T_{a}\right)\right| & \text { (付. 4) } \\
m_{a}=K_{m}\left|T_{0}-T_{a}\right| & \text { (付. 5) }
\end{array}
$$

上空は気温が低く減衰量は有限なので $T_{0}>T_{a}$ となる.
したがって．絶対值記号は不要となり図 1 の受信機では

$$
T_{a}=T_{0}-\frac{m_{a}}{m_{a}-m_{n}} \cdot T_{n}=333-\frac{m_{a}}{m_{a}-m_{n}} \cdot 160.5
$$

で雑音温度が得られる。

\section{〈付録 2〉降雨減衰と大気雑音の関係 ${ }^{1)-3\rangle}$}

電波が雨滴で吸収㧍よび散乱されたときに生じる減衰 と雑音温度の関係を考える ${ }^{1218)}$ ）乙のうち吸収にともな う雑音は抵抗隇衰器の場合と同様なので，乙こでは散乱 について考える.このとき生じる雑音は, 地面から発生す る熱雑音が雨滴で散乱されて受信されるすのと考える.

まず，受信空中線の真上にある 1 個の雨滴に注目す る.この雨滴で散乱された大地からの雑音のうち受信さ れる雑音の割合は付・図 1 で空中線から放射された電力 のうち雨滴で大地方向に散乱される割合に相当する.す なわち，全散乱電力のうち $\theta \leq 90^{\circ}$ の方向に散乱された 成分 $P_{B}$ である. $P_{B}=S_{B} P_{S}$ とすると文,

$$
S_{B}=\int_{0}^{2 \pi} \int_{0}^{\pi / 2} \overline{S_{R} S(\theta, \varphi)} \sin \theta d \theta d \varphi \quad \text { (付・7) }
$$

$S_{R S}(\theta, \varphi)$ は雨滴の散乱の境界值から求めた $\theta, \varphi$ 方向へ の散乱電力の時間平均で $\lambda, D$ の関数である(付.図 2). また， $\pi / 2<\theta<\pi$ の場合を $P_{F}=S_{F} P_{S}$ とすると $0<\theta<$ $\pi / 2, \pi / 2<\theta<\pi$ の散乱术減衰定数 $\alpha_{B}, \alpha_{F}$ は (4) 式之同様に,

$$
\alpha_{B}=\int_{0}^{\infty} N_{D} Q_{S}(D) S_{B}(D) d D \quad \text { (付 - 8) }
$$

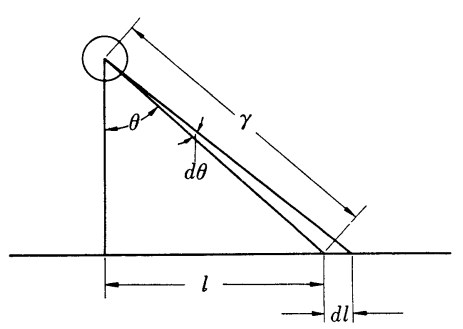

付.図 1

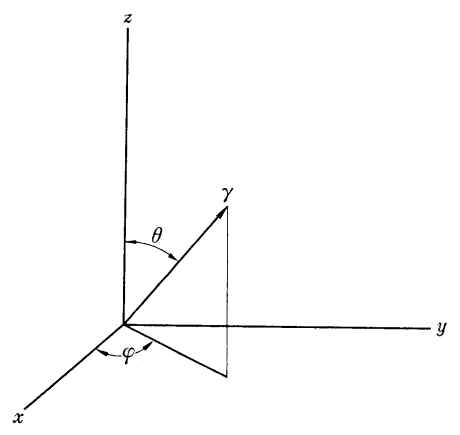

付·図 2 


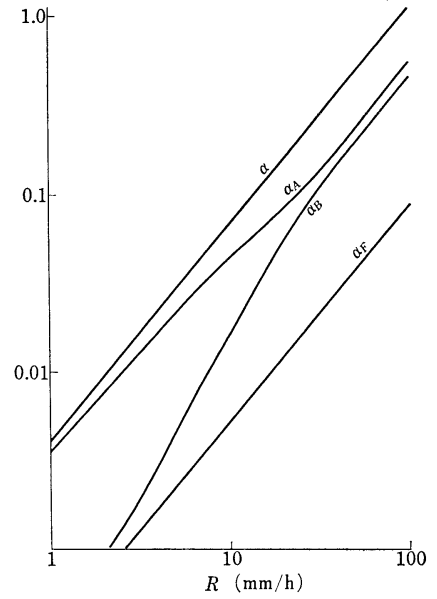

付.図 3 降雨強度と減衰率の関係

Relation between surface rain fall rate and attenuation rate.

$$
\alpha_{F}=\int_{0}^{\infty} N_{D} Q_{S}(D) S_{F} d(D) D
$$

となる. $Q_{S}(D)$ は直径 $D$ の雨滴の等価散乱断面積, $N_{D}$ は筫位体積中の直径 $D$ の雨滴の粒子数. また, $Q_{A}$
(D) を等価吸収断面積とすると，その減衰定数 $\alpha_{A}$ は,

$$
\alpha_{A}=\int_{0}^{\infty} N_{D} Q_{A}(D) d D
$$

この $N_{D}$ は当然降雨強度 $R$ の関数なので, Ryde の $R$ と $N_{D}$ 分布の観測例を用いて（付・8）（付・10）式 により $R$ ごとの $\alpha_{B}, \alpha_{F}, \alpha_{A}$ を求めると付·図 3 となる.

このようにして求めた $\alpha_{A}, \alpha_{B}, \alpha_{F}$ を用いて(7)式に より計算した結果が図 3 である.

上記の計算に用いた等価断面積は解析結果によると,

$$
Q_{T}(D)=\frac{\lambda^{2}}{2 \pi} \rho^{3}\left(c_{1}+c_{2} \rho^{2}+c_{3} \rho^{3}\right), \quad \rho \ll 1
$$

また， $Q_{A}(D), Q_{S}(D)$ はそれぞれ(付・11)式の実数部と 虚数部である.（付・11）式に用いた $\rho, c_{1}, c_{2}, c_{3}$ は水の複 素誘電率を $\varepsilon_{1}-j \varepsilon_{2}$ として,

$$
\begin{aligned}
& \rho=\frac{\pi D}{\lambda}, \quad c_{1}=\frac{6 \varepsilon_{2}}{\left(\varepsilon_{1}+2\right)^{2}+\varepsilon_{2}^{2}} \\
& c_{2}=\frac{\varepsilon_{2}}{15}\left\{\frac{3\left(7 \varepsilon_{1}^{2}+4 \varepsilon_{1}-20+7 \varepsilon_{2}^{2}\right)}{\left\{\left(\varepsilon_{1}+2\right)^{2}+\varepsilon_{2}^{2}\right\}^{2}}+\frac{25}{\left(2 \varepsilon_{1}+3\right)^{2}+4 \varepsilon_{2}{ }^{2}}+1\right\} \\
& \left.c_{3}=\frac{4}{3} \frac{\left(\varepsilon_{1}-1\right)^{2}\left(\varepsilon_{1}+2\right)^{2}+\varepsilon_{2}^{2}\left\{2\left(\varepsilon_{1}-1\right)\left(\varepsilon_{1}+2\right)-9\right\}+\varepsilon_{2}{ }^{4}}{\left\{\left(\varepsilon_{1}+2\right)^{2}+\varepsilon_{2}^{2}\right\}^{2}}\right)
\end{aligned}
$$

(付·12)

\section{テレビジョン 10 月特集号「画像走査」予定目次}

画像走查特集号によせて .東 大 滝 保 夫 画像工学に㧍ける走査 東 大 青木 昌治, NHK 稲津 稔 - 大石 嚴, 電通大 長谷川 伸

電子ビーム走査の問題点

(1) 概 説

(2) 撮像系に㧍ける走查の問題点

NHK 高橋 正彦

(3) テレビ受像系の走査 $\mathrm{NHK}$ 高 橋 正彦

立 小泉喜八郎・宮崎源太郎

（4）コンピューターディスプレィ……………………………………………東 芝 原尾 紀男・渡辺 一郎

（5）電子ビーム録画走査の問題…………………............................................... NHK 岩 村 総 一

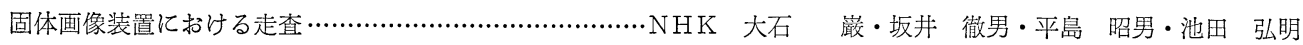
光ビーム走査

(1) 概 説 …………………………………………………………………………..東 大 多田 邦雄

（2）音響光学的および電気光学的光ビーム走査……………………………………東 大 多田 邦雄

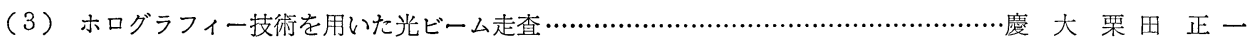
走査に関連した最近の話題

（1）新しく見出された物性を利用した走査 日電安藤隆男

(2) 走査速度変換 NHK 岩村 総一 